Konrad Aleksander Czernielewski

Muzeum Tradycji Niepodległościowych w Łodzi

iD ORCID ID: 0000-0001-7072-4678
OBLICZA WOJNY

TOM $3 \cdot$ MIASTO I WOJNA

ŁóDŹ2021 • ISBN 978-83-8220-556-5 • s. 171-193

https://doi.org/10.18778/8220-556-5.10

\title{
WALKI W MIEŚCIE W MYŚLI WOJSKOWEJ ROBOTNICZO-CHŁOPSKIEJ ARMII CZERWONEJ (1918-1946)
}

Streszczenie. Autor referatu przedstawił poglądy teoretyków i dowódców Robotniczo-Chłopskiej Armii Czerwonej (RKKA) na walki w mieście i ich zdobywanie, od powstania RKKA w lutym 1918 roku aż do końca drugiej wojny światowej. Omówił, jak wyższa kadra oficerska Armii Czerwonej zapatrywała się na kwestię specyfiki walki w rejonie zurbanizowanym - co współcześnie określa się terminem „czarnej taktyki”. Przedstawił także problem - zawsze istotny dla dowódców zarówno piechoty, broni pancernych, artylerii czy lotnictwa - czy miasta zdobywać "od frontu” czy raczej okrążać - zmuszając wroga do wycofania swych sił. Autor omówił to głównie na przykładzie walk w Stalingradzie i w Berlinie. Walki w tym ostatnim mieście w radzieckiej historiografii nazywane są Berlińską Strategiczną Operacją Ofensywną. Opisał także okoliczności natarcia na Bobrujsk w czasie realizacji Operacji Bagration. W tym ostatnim przypadku doszło do sporu między Józefem Stalinem, który był zwolennikiem zmasowanego natarcia na to miasto, a Konstantym Rokossowskim, który uparł się, aby nacierać koncentrycznie, wzdłuż obu brzegów Berezyny. Co ciekawe, w tym sporze generalissimus w końcu przyznał rację K. Rokossowskiemu. Autor przedstawił także nieudaną próbę zdobycia z marszu Kołobrzegu przez 45. Brygadę Pancerną Gwardii płk. Mikołaja Morgunowa ze składu 1. Armii Pancernej gen. płk. Michaiła Katukowa oraz udaną akcję zdobycia z marszu Częstochowy. W referacie przedstawione zostały poglądy najważniejszych dowódców radzieckich drugiej wojny światowej: Grigorija Żukowa, Konstantego Rokossowskiego, Iwana Koniewa, Iwana Bagramiana, Wasylija Czujkowa, Grigorija Nadysiewa oraz niemieckich: Ericha von Mannsteina i Heinza Guderiana.

Słowa kluczowe: Robotniczo-Chłopska Armia Czerwona, walki w mieście, walki o miasto, taktyka, strategia, manewr, okrążenie

Robotniczo-Chłopska Armia Czerwona (Rabocze-Kriestjanskaja Krasnaja Armija - dalej: RKKA), została utworzona dekretem Rady Komisarzy Ludowych Rosyjskiej Federacyjnej Socjalistycznej Republiki Radzieckiej z dnia 
15/28 stycznia 1918 r. Za datę jej powstania uznaje się natomiast dzień 10/ 23 lutego 1918 r., kiedy rozpoczęto masowe przyjmowanie ochotników do Armii Czerwonej ${ }^{1}$ W 1946 r. zmieniono jej nazwę na - Armia Radziecka.

Od czasów starożytnych miasta odgrywały ważną rolę w kampaniach wojennych. Zdaniem Tomasza Wójtowicza:

miasto, jako ośrodek cywilizacyjny, skupiający pewną liczbę mieszkańców, traktowano szczególnie, niezależnie od klimatu politycznego i poglądów etycznych na konflikt zbrojny. Wiele bitew, które przyczyniły się do obecnego kształtu geopolitycznego świata, stoczono pod murami ośrodków miejskich po to, by je zdobyć. Dominacja nad miastami oznaczała przejęcie kontroli nie tylko nad danym terytorium, ale także nad szlakami komunikacyjnymi, centrum władzy przeciwnika, centrum administracyjnym, kulturowym czy religijnym. (...) Zdobycie Alezji przypieczętowało dominację Rzymu nad Galią na kolejne setki lat, natomiast upadek i zniszczenie Jerozolimy, a w wraz z nią świątyni żydowskiej, dało początek długiej diasporze tej społeczności ${ }^{2}$.

W okresie nowożytnym, choć miasta nie miały już warownego charakteru, były traktowane jako miejsca służące do zatrzymania natarcia nieprzyjaciela. Jako przykład mogą służyć walki w okresie wojny trzydziestoletniej (16181648), wojny napoleońskie, wojna krymska (1853-1856), a zwłaszcza walki o Sewastopol ${ }^{3}$ czy wojna secesyjna (1861-1865). Ta ostatnia przyniosła jeden nowy, ale wielce tragiczny aspekt walk o miasto, jakim są cierpienia i tragedie ludności cywilnej. Takim dramatycznym symbolem wojny secesyjnej stała się Atlanta w Georgii. Wprawdzie walki w lipcu 1864 r. toczyły się pod miastem, ale generał William Tecumseh Sherman uznał, iż musi „usłyszeć jęk Georgii”‘. Amerykański historyk Bernard A. Weisberger napisał: „Najpierw spalono

${ }^{1}$ Ю. Корабльов, Зашита Республики. Как создавалась Рабоче-Крестьянскал Краснал Армия. Переписка на исторические темь:: диалог ведёт читатель, Москва 1989, s. 160; Военный Энщиклопедический Словарь, Москва 1983, s. 370, 609.

2 T. Wójtowicz, Rola miast $w$ strategii militarnej. Prowadzenie walk $w$ terenie zurbanizowanym na przyktadzie II wojny w Zatoce Perskiej, „Zeszyty Naukowe Wyższej Szkoły Europejkkiej im. ks. Józefa Tischnera w Krakowie" 2008, nr 4, s. 131-133. Vide: A. Krawczuk, Gajusz Juliusz Cezar, Warszawa 1990, s. 20-65; A. Chojnowski, Izrael, Warszawa 2003, s. 40 i n.; J.A. Ostrowski, Rozwój i upadek Imperium Romanum, [w:] Wielka historia świata, t. 3: Świat okresu cywilizacji klasycznych, red. A. KrawCZuK, Kraków 2005, s. 311 i 337; P. Southern, Juliusz Cezar, Warszawa 2002, s. 100-105.

${ }^{3}$ L. BAzYLOw, Historia Rosji, Warszawa 1985, s. 239; M. KLIMECKI, Krym 1854-1855, Warszawa 2006, s. 232.

${ }^{4}$ B.A. Weisberger, Wojna secesyjna 1861-1865, [w:] Historia Stanów Zjednoczonych Ameryki, red. W. Nugent, H. Parafianowicz, t. 3: 1848-1917, Warszawa 1985, s. 61. 
Atlantę. Stamtąd kolumny wojsk posuwały się na południe 50-milową ławą, wyrywając po drodze szyny kolejowe i druty telegraficzne, paląc uprawy na polach, wyrzynając bydło, podpalając domy i stodoły”`. Była to zapowiedź okrucieństw wojen następnego stulecia.

W latach I wojny światowej nie walczono w miastach, a zajmowano je w wyniku wygrania bitwy koło aglomeracji miejskiej. Było tak m.in. w przypadku Łodzi ${ }^{6}$. Do historii wojskowości polskiej i powszechnej przeszły natomiast walki o twierdze, na froncie wschodnim takie jak Przemyśl i Osowiec, a w zachodnioeuropejskim teatrze działań bojowych - Liège czy Antwerpia? Paradoksalnie do walk w samych miastach doszło już po zakończeniu wojny w okresie zamieszek rewolucyjnych w Niemczech w latach 1918-1919 .

Jednym z pierwszych wojskowych, który zainteresował się bojami w rejonie zurbanizowanym, był polski oficer, ppłk Stefan Rowecki. W 1928 r. Wojskowy Instytut Naukowo-Wydawniczy opublikował jego opracowanie o walkach w mieście?. Strona radziecka znała tę pracę. W Związku Socjalistycznych Republik Radzieckich (dalej: ZSRR) tłumaczono także prace Władysława Sikorskiego i Stefana Mossora. Sam S. Rowecki tłumaczył zainteresowanie walkami ulicznymi w Niemczech po zakończeniu I wojny światowej niebezpieczeństwem grożącym Polsce ze strony wschodniego sąsiada. Dowódcy Armii Czerwonej, którzy także analizowali doświadczenia niemieckie, mogli bowiem „przy natarciu wojska czerwonego z frontu, równocześnie wbić sztylet w plecy. Tym sztyletem mają być wywołane na tyłach frontu bojowego zaburzenia, rozruchy, zamieszki, bunty, sabotaże, słowem - działania dywersyjne"10.

5 Ibidem, s. 61-64.

${ }^{6}$ K.A. CZERNIELEWsKi, Operacja tódzka 1914 roku. W stulecie walk o nasze miasto, „Kronika Miasta Łodzi” 2014, nr 3(76), s. 84-92.

7 J. Pajewski, Pierwsza wojna światowa, Warszawa 1991, s. 130, 192, 288, 290, 299, 331, 714; W. Suworow, Klęska, Poznań 2010, s. 300. Vide: J. Różański, Twierdza Przemyśl, Rzeszów 1983; B. PerzyK, Twierdza Osowiec 1882-1915, Warszawa 2004; A. WAP, Twierdza Osowiec - zarys dziejów, Białystok 1994; https://wikipedia.org/wiki/Twierdza_Li\%C3\%A8ga (dostęp: 7 XII 2020).

${ }_{8}$ Należałoby jednak pamiętać o francuskich doświadczeniach z lat trzydziestych i czterdziestych XIX w. w Algierii. Vide: M. BACZKowski, Kontynent europejski w latach 1789-1849, [w:] Wielka historia świata, t. 9: Swiat w latach 1800-1850, red. A. CHWALBA, Kraków 2006, s. 455-456; Britannica. Edycja polska, t. 1, Poznań 1997, s. 312.

9 S. RoweCKI, Walki uliczne, Warszawa 1928.

${ }^{10}$ IDEM, s. 15-16. O opracowaniach teoretycznych S. Roweckiego - vide: G. GoŁĘBIEWsKI, Zanim zostat „Grotem”. Stużba Stefana Roweckiego w wojsku II Rzeczypospolitej do 1939 r., Warszawa 1995, s. 197-219. Autor pisze o wysokiej ocenie opracowania S. Roweckiego dokonanej przez kadrę 
W latach międzywojennych zarówno strona polska, jak i radziecka nawzajem „podpatrywały” się. Już pod koniec 1930 r. ppłk dypl. Jan Kowalewski, polski attaché wojskowy w ZSRR w latach 1928-1933, raportował z Moskwy: "Jeżeli nie można jeszcze powiedzieć, że ZSRR szykuje się do wojny, to można twierdzić, że szykuje się jak do wojny"11. Praktycznie do końca lat trzydziestych w kręgach decydenckich Sztabu Generalnego Wojska Polskiego (dalej: SG WP), Ministerstwa Spraw Wojskowych (dalej: MSWojsk.) oraz Generalnego Inspektoratu Sił Zbrojnych (dalej: GISZ) uważano, iż głównym wrogiem Polski w przyszłej wojnie będzie Związek Radziecki, a dopiero w 1938 r. zweryfikowano tę opcję, uznając, iż pierwsi zaatakują nasz kraj Niemcy. Podpatrywano zatem przygotowania wojenne ZSRR, z niepokojem konstatując, że niepokojąco rośnie budżet Armii Czerwonej ${ }^{12}$. Wśród wielu polskich oficerów wyróżniał się zwłaszcza wspomniany J. Kowalewski, którego działalność wysoko ocenia m.in. Aleksander Smoliński ${ }^{13}$.

W przekazywanych raportach brak jest jednak informacji na pogląd radzieckich dowódców na walki w mieście. Wydaje się, iż przyczyną takiego stanu rzeczy jest zbyt skromny stan wiedzy co do przyszłego charakteru walk w mieście, walk nie z formacjami dywersyjnymi, ale walk regularnych armii.

kierowniczą RKKA (s. 211). Pracami polskimi cenionymi przez wojskowych ekspertów niemieckich i radzieckich były m.in.: W. SIKORSKI, Przyszta wojna - jej możliwości i charakter oraz zwiazzane z nimi zagadnienia obrony kraju, Warszawa 1934; S. MOSSOR, Sztuka wojenna w warunkach nowoczesnej wojny, Warszawa 1938.

${ }_{11}$ Archiwum Akt Nowych w Warszawie (dalej: AAN), Ambasada w Moskwie, sygn. 94, Raport ppłk. SG Jana Kowalewskiego z 29 XI 1930 r., k. 1; K.A. Czernielewski, Polski wywiad wojskowy w latach wojny z Rosja bolszewicką. As stużb specjalnych II Rzeczypospolitej - Jan Kowalewski, Łódź 2020, s. 39-43. O roli attachatów wojskowych - vide: R. MAJZneR, Attachaty wojskowe Drugiej Rzeczypospolitej 1919-1945. Strukturalno-organizacyjne aspekty funkcjonowania, Częstochowa 2011; A. PepŁoński, Wywiad a dyplomacja II Rzeczypospolitej, Toruń 2004.

${ }^{12}$ Centralne Archiwum Wojskowe - Wojskowe Biuro Historyczne (dalej: CAW WBH), Oddział II Sztabu Generalnego (dalej: SG), sygn. I.303.4.3169, Siły zbrojne ZSRR, t. 3, Organizacja O.de.B. i dyslokacja formacji dyspozycyjnych, cz. 2, O.deB. i dyslokacja formacji dyspozycyjnych, z. 1. Opracowanie, Oddział II SG 1. dz. 8800/II R.T.O, Warszawa 29 II 1936; AAN, Instytucje wojskowe 1918-1939, sygn. 296/I/82. Raport Attaché Militaire à Moscou z 25 XI 1930 r., karty bez paginacji.

13 A. SMOLIŃsKi, Armia Czerwona oraz sowiecki potencjat militarny z lat dwudziestych i trzydziestych XX w. w dokumentach Oddziatu II Sztabu Gtównego Wojska Polskiego. Przyczynek do dziejów i efektywności wywiadu wojskowego II Rzeczypospolitej, [w:] Studia nad wywiadem i kontrwywiadem Polski w XX wieku, t. 3, red. W. SKÓRA, P. SKUBISZ, Szczecin 2016, s. 85. 
W I wojnie światowej starć takich nie było, lata puczu bolszewickiego i wojny domowej w Rosji, a także walk rewolucyjnych w początkowych latach istnienia Republiki Weimarskiej także nie przyniosły takowych informacji. Praktycznie wszyscy uczyli się taktyki walk w mieście dopiero podczas II wojny światowej ${ }^{14}$.

Rodzi się pytanie, jakie wnioski wyciągnięto z lat wojny domowej w Hiszpanii, stanowiącej swoiste preludium II wojny światowej. Strona radziecka wspierała oddziały republikańskiej Hiszpanii, dostarczając ochotników, a także sprzęt bojowy. Niemniej w okresie tzw. bitwy o Madryt (październik 1936 - marzec 1937) walki toczyły się głównie na przedpolach oblężonej przez frankistów stolicy Hiszpanii, pomijając sporadyczne rajdy wojsk gen. Francisco Franco na przedmieścia miasta. Natomiast Józef Stalin traktował hiszpańską wojnę domową jako swoisty poligon doświadczalny dla własnego sprzętu oraz swoich specjalistów wojskowych, także tych odpowiedzialnych za wyposażenie bojowe Armii Czerwonej ${ }^{15}$.

W czasie walk w Polsce w 1939 r. nie było de facto znaczących walk w miastach. W przypadku Warszawy toczyła się ona na przedmieściach stolicy Pol$\mathrm{ski}^{16}$. Trudno też powiedzieć, na ile w Armii Czerwonej wyciągnięto wnioski z błędów popełnionych przez jej dowódców podczas walk o Grodno. Mimo sporej przewagi nad stroną polską RKKA straciła w tym mieście 19 czołgów i 3 samochody pancerne ${ }^{17}$. Wydaje się wątpliwe, że analizowano te błędy po

${ }_{14}$ Armia Czerwona w przededniu najcięższej próby. Materiaty z posiedzenia Rady Wojennej Robotniczo-Chtopskiej Armii Czerwonej w dniach 23-31 grudnia 1940 r., oprac. J. BUDZIŃSKI, C. GRZELAK, Z. MATUSZAK, Warszawa 2006. W naradzie tej wzięli udział m.in.: S.K. Timoszenko, I. Koniew (wówczas dowódca Zabajkalskiego Okręgu Wojskowego), G. Żukow (dowódca Kijowskiego Specjalnego Okręgu Wojskowego).

15 РККА и Гражданскал война в Испании. Сборники информачионных материалов Разведьвательного управления, Москуа 2020, s. 52-54; M. WоŁOS, Udziat obywateli Zwiazku Sowieckiego w wojnie domowej w Hiszpanii w latach 1936-1939, „Acta Universitatis Lodziensis. Folia Historica” 2016, t. 97, s. 31-63; https://artsandculture.google.com/exhit/hiszpanska-wojna-domowa (dostęp: 5 I 2021).

16 J. ODZIEMKOWsKi, Warszawa w wojnie obronnej 1939 roku, Warszawa 1989, s. 101-134; M.P. DesZCZYŃSKI, Warszawa niepokonana, [w:] II wojna światowa, red. K. KUREK, t. 2 (Obrona Polski), Warszawa 2009, s. 77-85; K.A. CZERnieLEWsKi, Kampania 1939 roku. Przebieg, kulisy, mity..., Łódź 2019, s. 42-44. Vide: L. GŁOWACKI, Obrona Warszawy i Modlina na tle kampanii wrześniowej 1939, Warszawa 1985.

17 C. GrzelaK, Wilno-Grodno-Kodziowce 1939, Warszawa 2002, s. 128-129; IDEM, Kresy w czerwieni, Warszawa 1998, s. 336-338. 
straszliwych stratach w kadrze dowódczej w wyniku czystek dokonanych przez J. Stalina. Zdaniem A. Smolińskiego ${ }^{18}$ nie tylko szeregowym żołnierzom, ale i kadrze dowódczej RKKA brakowało całkowicie inicjatywy, co będzie szczególnie istotne $\mathrm{w}$ prowadzeniu walki $\mathrm{w}$ rejonach zurbanizowanych, zwłaszcza zaś w dużych miastach. Wszelkie braki w wyszkoleniu Armii Czerwonej bezlitośnie obnażyła wojna z Finlandią przełomu lat 1939-194019. Zdaniem Sebastiana Chojnackiego ${ }^{20}$ zarówno doświadczenia walk w Hiszpanii, jak i doświadczenia z agresji na Polskę i Finlandię nie wpłynęły na radziecką sztukę operacyjną. Czesław Grzelak napisał, że po doświadczeniach wojny z Finlandią „Stalin zrozumiał, że Armia Czerwona nie jest przygotowana do prowadzenia nowoczesnej wojny zarówno pod względem struktury i organizacji dowodzenia, zaopatrzenia, a przede wszystkim szeroko rozumianego przygotowania bojowego w zakresie umiejętności realizacji zadań pola walki”21. Trzeba jednak podkreślić z całą mocą, że wszystkie strony konfliktu dopiero w środkowym okresie II wojny światowej zaczęły „uczyć się” prowadzenia walki w ośrodkach miejskich.

Jedną z najważniejszych bitew stoczonych przez Armię Czerwoną w latach Wielkiej Wojny Ojczyźnianej, jak określają Rosjanie swoje walki z wojskami III Rzeszy, była bitwa stalingradzka. Obrona Stalingradu przeszła do militarnej legendy i to nie tylko Armii Czerwonej. To w tym mieście, położonym w dolnym biegu Wołgi, prawie każdy dom stawał się twierdzą, o którą toczyły się walki. Zdziesiątkowani obrońcy przyjęli na siebie atak przeważających sił niemieckiej Grupy Armii „Południe”, aby w tym czasie na zapleczu frontu marszałek Grigorij Żukow mógł przygotować kontruderzenie na słabsze skrzydła wroga - uderzenie, które zmieniło bieg wojny ${ }^{22}$. Uczestnik bitwy o Stalingrad, szef niemieckiego sztabu łącznikowego przy rumuńskiej 4. Armii, Hans Doerr, w swej książce Der Feldzug nach Stalingrad napisał: „Bitwa pod Stalingradem stanowiła dla Niemiec jedną z najcięższych klęsk w ich historii, a dla Rosji

\footnotetext{
18 A. SMOLIŃSKI, op. cit., s. 94.

19 Vide: T. Konecki, Wojna radziecko-finska 1939-1940, Warszawa 1998; M. КоєОмYJeC, Wojna zimowa 1939-1940. Warszawa 2002.

20 S. CHOJNACKI, Sowiecka sztuka operacyjna w latach 1940-1941, „Studia z Dziejów Rosji i Europy Środkowo-Wschodniej” 2014, t. 49, nr 2, s. 183.

${ }^{21}$ C. GrzelaK, Armia Czerwona po wojnie polsko-rosyjskiej 1919-1921, „Studia z Dziejów Wojskowości" 2014, t. 3, s. 262.

22 T. WójTOwicz, op.cit., s. 134; K. RoKOssowski, Żotnierski obowiazzek, Warszawa 1973, s. 227.
} 
największe zwycięstwo (...) Stalingrad zaś stał się początkiem jej przeistoczenia się w jedno z dwóch największych mocarstw świata"23. Znaczenie Stalingradu podkreślał w swoich wspomnieniach gen. Heinz Guderian, mówiąc o tej bitwie jako „katastrofie pod Stalingradem”24, a niemiecki historyk gen. Kurt von Tippelskirch stwierdził w 1954 r., że nad Wołgą wydarzyło się coś, czego nie doznały Niemcy od początku XIX w. ${ }^{25}$

Autorami zwycięstwa w Stalingradzie są de facto dwaj radzieccy dowódcy: Grigorij Żukow i Wasilij Czujkow. Pierwszy z nich od 26 sierpnia 1942 r. był zastępcą naczelnego dowódcy, a więc samego J. Stalina. W dniu 29 sierpnia tegoż roku powierzono mu obronę Stalingradu. Zdaniem Tima Newarka, dyktator ZSRR w obliczu wręcz tragicznej sytuacji na froncie zaufał G. Żukowowi, a podczas walk o Stalingrad dał mu wolną rękę i nie interweniował politycznie ${ }^{26}$. Przypomina to trochę późniejszą sytuację z okresu 22 czerwca - 31 sierpnia 1944 r. podczas realizacji Operacji „Bagration”. Józef Stalin uważał, iż należy przeprowadzić zmasowane natarcie na Bobrujsk, natomiast Konstanty Rokossowski uparł się, aby nacierać koncentrycznie, wzdłuż obu brzegów Berezyny. Co ciekawe, w tym sporze generalissimus w końcu przyznał rację K. Rokossowskiemu. Ten ostatni uważał, iż lepiej okrążać miasto niż je zdobywać, atakując frontalnie. W rezultacie po przyjęciu koncepcji K. Rokossowskiego doszło do prawie całkowitego zniszczenia niemieckich sił Grupy Armii „Środek” na Litwie, Białorusi i wschodniej Polsce. Podczas narady, w której uczestniczył także marszałek G. Żukow, ludowy komisarz spraw zagranicznych Wiaczesław Mołotow oraz członek Państwowego Komitetu Obrony Grigorij Malenkow, K. Rokosowski dwukrotnie "pozwolił sobie” wyrazić odmienne zdanie niż J. Stalin. W czasie przerwy w naradzie W. Mołotow i G. Malenkow wyszli za K. Rokossowskim, pytając go, czy „zdaje sobie sprawę, z kim się spiera?”. Gdy po raz trzeci dowódca 1. Frontu Białoruskiego podtrzymał swoją decyzję, generalissimus ZSRR wyraził zgodę, stwierdzając, że lubi generałów,

${ }^{23}$ Cyt. za: K. KaczmareK, Stalingrad 1942-1943, Warszawa 1985, s. 221.

${ }^{24}$ H. GUDERIAN, Wspomnienia żotnierza, Warszawa 1958, s. 225.

25 К. ТИППЕльСКИРХ, История Второй мировой войны, Москва 1956, s. 256-264.

26 T. Newark, 50 bitew, które zmienity bieg historii nowożytnej, Poznań 2002, s. 116. Rolę G. Żukowa w okresie walk pod Stalingradem podważa WiKTOR SuwOrow (Cofam wypowiedziane stowa, Poznań 2014, s. 434), powołując się na opinię marszałka lotnictwa Aleksandra Gołowanowa, do wybuchu wojny funkcjonariusza służb specjalnych, a w 1939 r. nadzorującego z ich ramienia G. Żukowa podczas walk granicznych radziecko-japońskich nad rzeką Chałchyn Goł w Mongolii. 
którzy znają swoje rzemiosło i mają własne zdanie. Iwan Bagramian, wówczas dowódca 1. Frontu Nadbałtyckiego, tak wspominał tamto wydarzenie:

Wbrew propozycji Sztabu Generalnego, by wojska frontu wykonały potężne uderzenie tylko na jednym odcinku przełamania, Konstanty Konstantynowicz [Rokossowski] powziął zasadną decyzję utworzenia dwóch zgrupowań uderzeniowych, które miały przełamać obronę przeciwnika na dwóch kierunkach, aby następnie natarciem w głąb okrążyć i rozbić główne zgrupowanie nieprzyjaciela. Propozycja ta spotkała się z poparciem marszałka Żukowskiego i Wasilewskiego; została także zatwierdzona przez naczelnego dowódcę. Sądzę, że dla generała armii Rokossowskiego naczelny dowódca żywił szczególną sympatię. Timoszenko opowiadał mi, że Stalin porównywał Rokossowskiego z Dzierżyńskim (...) „tylko Feliks był trochę twardszy i sroższy" ${ }^{\prime 2}$.

W gruncie rzeczy dowódcą, który wypracował taktykę walki w zrujnowanym mieście, był Wasilij Czujkow. Jest to ciekawa postać w panteonie radzieckich głównych dowódców z lat II wojny światowej. Absolwent Akademii Wojskowej im. Michaiła Frunzego, w latach 1940-1942 attaché wojskowy w Chinach i doradca Czang Kaj-szeka, został w marcu 1942 r. odwołany do kraju. Od maja tego roku był dowódcą 1. Armii Rezerwowej, przemianowanej wkrótce na 64. Armię. We wrześniu 1942 r. został dowódcą 62. Armii, związku operacyjnego najważniejszego w strukturze obrony Stalingradu. Generał W. Czujkow był zdecydowanym dowódcą, który opanował rozprzężenie i objawy paniki w 62 . Armii. Zdobył szacunek swoich żołnierzy, odwiedzając ich na pozycjach bojowych podległych mu pododdziałów ${ }^{28}$, a swoje stanowiska dowodzenia miał blisko linii frontu. Zjednało mu to sympatię podwładnych, choć jak większość wyższych dowódców radzieckich często poświęcał ich życie bez większego żalu. Wyjątkiem był w tej mierze właściwie jedynie K. Rokossowski.

Wasilij Czujkow, wobec przewagi Niemców w powietrzu oraz w ilości dział, przyjął taktykę działania własnych pododdziałów jak najbliżej niemieckich, tak aby nieprzyjaciel nie mógł wykorzystać swej przewagi w uzbrojeniu, nie prowadząc obstrzału i bombardowania własnych pododdziałów. Walki w Stalingradzie często przeradzały się bowiem w starcia małych pododdziałów:

${ }^{27}$ I. BAgramian, Tak wykuwalismy zwycięstwo, Warszawa 1980, s. 304; W. BIAŁKOwsKi, Rokossowski - na ile Polak?, Warszawa 1994, s. 73-78.

${ }^{28} \mathrm{~W}$ terminologii wojskowej pododdział to szczebel organizacyjny od drużyny do batalionu włącznie. Pułk oraz samodzielny batalion to oddziały, natomiast brygady i dywizje to związki taktyczne. 
plutonów czy kompanii. Rodziło to potrzebę samodzielności w podejmowaniu decyzji przez dowódców niższej rangi, na co mocno zwracał uwagę nie tylko W. Czujkow, ale także G. Żukow. Pierwszy z nich stwierdził, iż przeszedł „stalingradzką akademię walk w terenie zabudowanym"29. Walki często toczyły się o każde piętro budynków, niekiedy najlepszą bronią była zaostrzona łopatka piechoty, a do osłony własnych pozycji wykorzystywano zamarznięte zwłoki swoich współtowarzyszy walki. Wasilij Czujkow przytacza w swych wspomnieniach meldunek jednego ze swych podkomendnych: „Sytuacja się zmieniła. Przedtem my byliśmy na górze, a Niemcy na dole. Teraz wyparliśmy ich z dołu, ale za to przedostali się na górę i bijemy się na wyższych piętrach" ${ }^{30}$. Podczas walk w Stalingradzie często przed zajęciem budynku wypalano go, po prostu wiadomo było, że taki obiekt nie zapali się już ponownie.

Stalingrad bez żadnej przesady można nazwać piekłem na ziemi. W. Czujkow wspominat: „W dzień nie można było podnieść głowy. Hitlerowcy obstrzeliwali każdy kamień, każdy okop, każdy metr ziemi”31. Do swoich żołnierzy miał powiedzieć: „Utrzymamy to miasto albo zginiemy”32.

Takiego rodzaju starcia wyzwalały wśród żołnierzy walczących stron niskie instynkty. Jeden z żołnierzy niemieckich wspominał:

Każdy Rosjanin przyłapany na rabowaniu niemieckich trupów był rozstrzeliwany na miejscu. Egzekucji nie wykonywały plutony egzekucyjne. Oficer wyjmował pistolet i strzelał. (...) Kiedyś obserwowałem z przerażeniem, jak jeden z (...) żołnierzy przywiązał do bramy za ręce trzech jeńców. A potem wrzucił granat do kieszeni jednego z nich, wyciągnął zawleczkę i uciekt ${ }^{33}$.

Dodajmy, iż dowódcy radzieccy wcale nie zwalczali tego typu czynów u swoich żołnierzy. W końcowej fazie wojny Armię Czerwoną nazywano najokrutniejszą armią świata. Jej dowódcy byli jednocześnie bezwzględni dla swoich żołnierzy. W. Czujkow miał podobno zwyczaj strzelać w plecy dezerterom ${ }^{34}$. W czasie walk pod Stalingradem, a zwłaszcza w samym mieście, Rosjanie wypracowali taktykę i metodę walk w rejonach zurbanizowanych. G. Żukow

\footnotetext{
29 Cyt. za: S. Gowin, Berlin 1945, Warszawa 2005, s. 50; K. KACZMAreK, op. cit., s. 77-103.

30 W. Czujкow, Początek drogi, Warszawa 1962, s. 110.

31 В. Чуйков, 180 дней в огне сражений. Из записок командарма 62-й, Москва 1962, s. 79.

32 N. Cawthorne, Dowódcy i generatowie. Prawdziwe historie, Warszawa 2014, s. 194.

33 T. NEWARK, op. cit., s. 119.

${ }^{34}$ S. GowIN, op. cit., s. 16; https://pl.wikiquote.org/wiki/Wasilij_Czujkow (dostęp: 17 I 2021).
} 
pod koniec lat sześćdziesiątych stwierdził: „Dla mnie osobiście obrona Stalingradu, przygotowanie przeciwnatarcia i udział w powzięciu decyzji co do operacji na południu kraju miały szczególne znaczenie. Tutaj zdobyłem znacznie większą praktykę w organizowaniu przeciwnatarcia niż w 1941 roku w rejonie Moskwy, gdzie ograniczone siły nie pozwoliły okrążyć nieprzyjacielskiego zgrupowania" 35 .

Podczas walk o Stalingrad zginęło ok. 147 tys. żołnierzy niemieckich, 91 tys. trafiło do niewoli, z której wróciło jedynie niecałe 6 tys. Niemców. Stalingrad był tragedią nie tylko Niemców, ale także ich sprzymierzeńców: rumuńskiej 1. Dywizji Kawalerii i 20. Dywizji Piechoty oraz chorwackiego 369. pułku piechoty. Strona rosyjska straciła ok. 50 tys. żołnierzy, zginęło też ponad 42 tys. osób cywilnych ${ }^{36}$.

Kończąc tę część rozważań, warto może przytoczyć opinię jednego z najsławniejszych dowódców alianckich z lat II wojny światowej Bernarda L. Montgomery’ego, o tym, jacy powinni być przywódcy polityczni i dowódcy wojskowi:

\begin{abstract}
Przywódca musi - moim zdaniem - wiedzieć, czego chce. Musi jasno widzieć swój cel, a następnie dążyć do osiągnięcia go, musi zapoznać wszystkich ze swymi zamierzeniami i z podstawowymi zasadami polityki. Musi więc, w istocie rzeczy, być niewzruszonym przewodnikiem jasno wytyczającym drogę. Konieczne jest, aby stworzył to, co nazwałbym atmosferą, w której żyją i pracują jego podwładni. Znałem dowódców, którzy uważali, że z chwilą gdy opracowali plan i wydali rozkazy, nie mają potrzeby brać udziału w ich wykonywaniu, oprócz oddziaływania na bitwę odwodami. Jest to ogromny błąd. Współczesną bitwę bardzo łatwo jest wykoleic ${ }^{37}$.
\end{abstract}

Wydaje się, że dowodzący w bitwie stalingradzkiej: wspomniani już G. Żukow, W. Czujkow czy K. Rokossowski (w czasie bitwy dowódca Frontu Dońskiego), a także: Aleksander Wasilewski (szef Sztabu Generalnego RKKA), Andriej Jeremienko (dowódca Frontu Stalingradzkiego, a następnie Południowego), Nikołaj Woronow (dowódca artylerii RKKA) i Nikołaj Watutin (dowódca Frontu Południowo-Zachodniego) - tego błędu nie popełnili.

35 G. ŻuKOw, Wspomnienia i refleksje, Warszawa 1973, s. 449.

36 T. Newark, op. cit., s. 119; T. KondrackI, Stalingradzkie piekto na ziemi, [w:] II wojna światowa, red. K. KUReK, t. 10 (Front Wschodni), Warszawa 2009 s. 53-68; K. KaCZMAreK, op. cit., s. 216-223; www.sww.w.szu.pl/index.php.?id=bitwa_stalingrad (dostęp: 30 XII 2020).

37 B.L. Montgomery, Wspomnienia, Warszawa 1996, s. 87. 
Jeden z najwybitniejszych niemieckich dowódców lat II wojny światowej Erich von Manstein ocenił działania strony niemieckiej nad Wołgą: „Przyczyn zagłady 6 Armii należy szukać oczywiście w tym, że Hitler - niewątpliwie ze względów prestiżowych - wzbraniał się przed dobrowolnym oddaniem Stalingradu. To, że jednak 6 Armia w ogóle mogła znaleźć się w takim położeniu, tkwi w udokumentowanych błędach operacyjnych popełnionych przez naczelne dowództwo niemieckie"38.

Doświadczenia zdobyte podczas walk o Stalingrad Rosjanie zdyskontowali podczas operacji berlińskiej. Na szybkie zdobycie Berlina naciskał rosyjską Stawkę ${ }^{39}$ sam J. Stalin, zaniepokojony wiosną 1945 r. sytuacją, jaka ukształtowała się na froncie zachodnim. W dniu 7 marca Amerykanie zdobyli bowiem most na Renie, a w połowie tegoż miesiąca uchwycili dwa przyczółki na wschodnim brzegu Łaby. Część społeczeństwa niemieckiego wierzyła, że Zachód skieruje swe wojska przeciwko „bolszewickiej nawale na Europę”, inni liczyli na separatystyczną kapitulację Niemiec przed aliantami zachodnimi. Nie wiedziano, że przywódcy Wielkiej Brytanii i USA, Winston Churchill i Franklin Delano Roosevelt, wykluczali już od końca 1943 r. możliwość odrębnej kapitulacji ${ }^{40}$.

Niemniej J. Stalin, polityk nieufny, wolał samodzielnie zająć stolicę III Rzeszy, co by mu dawało mocną kartę przetargową w powojennym układzie sił międzynarodowych jako niekwestionowanemu pogromcy III Rzeszy. Według Ławrentija Berii, szefa NKWD, w Berlinie miały znajdować się dewizy i złoto Banku Rzeszy oraz kadra naukowa z zapasem uranu z Kaiser Wilhelm Institut - niemieckiego centrum fizyki jądrowej. Wiadomości posiadane przez NKWD były już niezgodne z aktualnymi faktami, gdyż naukowcy opuścili stolicę, a uran, złoto i dewizy zdążono wywieźć. Jednak zajęcie stolicy Niemiec przed mocarstwami anglosaskim było bardzo ważne, zarówno z powodów czysto militarnych, jak i geopolitycznych ${ }^{41}$.

Walki o miasto były bardzo zacięte i krwawe dla obu stron. W tak dużym mieście, wśród jego ruin, gdzie w mniejszym stopniu można było wykorzystać broń pancerną, główna rola przypadła piechocie ${ }^{42}$, która chociażby z uwagi na

\footnotetext{
38 E. von Manstein, Stracone zwycięstwa. Wspomnienia 1939-1944, Warszawa 2001, t. 2, s. 8.

39 „Stawka” to po rosyjsku kierownictwo (kwatera główna) Najwyższego Naczelnego Dowództwa.

40 S. Gowin, op. cit., s. 11.

${ }^{41}$ Ibidem, s. 15.

${ }^{42}$ Ibidem, s. 4-5.
} 
brak znajomości topografii tak dużego miasta była skazana na ogromne straty. Dyktator ZSRR rozkaz rozpoczęcia ofensywy wydał w Moskwie 1 kwietnia, nakazując rozpocząć ją 16 kwietnia, a zakończyć dwa tygodnie później. O miano zdobywcy Berlina rywalizowało dwóch radzieckich marszałków: G. Żukow - dowódca 1. Frontu Białoruskiego, i Iwan Koniew - dowodzący 1. Frontem Ukraińskim. Obydwaj stawiali sobie za cel zdobycie stolicy Niemiec, co dawało J. Stalinowi szansę na skuteczne przeprowadzenie operacji berlińskiej, określanej w historiografii radzieckiej i rosyjskiej jako „Berlińska Strategiczna Operacja Ofensywna”.

Trzeba stwierdzić, iż wiele miejscowości na podejściach do Berlina było dobrze przygotowanych do obrony. Odrzańsko-nyska rubież obronna i berliński rejon umocniony zbudowane były na głębokość prawie $100 \mathrm{~km}$. W dniu 1 lutego 1945 r. ogłoszono stolicę Rzeszy twierdzą. Stworzono trzy pierścienie obrony, a cały obszar miasta podzielono na dziewięć sektorów obronnych - osiem na obwodzie obrony oraz jeden centralny, obejmujący Reichstag, Kancelarię Rzeszy oraz siedzibę Gestapo przy Prinz-Albrecht-Strasse 8. Analizując możliwości obrony samego miasta, należy przyznać, że jego obrońcy nie dysponowali ogromną siłą. Były to jedynie: dywizja artylerii plot., pułk „Grossdeutschland”, kilka batalionów policji i saperów, 200 batalionów Volkssturmu złożonych ze starszych ludzi, młodzieży z Hitlerjugend oraz inwalidów. Łącznie było to 300 tys. ludzi, 3 tys. dział, 250 czołgów i dział szturmowych. Obrona dysponowała też tysiącem dużych żelbetonowych schronów ${ }^{43}$. Zdaniem jednego z żołnierzy Volkssturmu, obroną rządziły: „trzy żywioły - wiara w Luftwaffe, cudowną broń, którą obiecał führer, paniczny lęk przed najokrutniejszą armią świata, którą straszył führer, i wreszcie rozkaz führera" ${ }^{\prime 4}$. Niewątpliwie prawdą jest, że krasnoarmiejcy w Berlinie nie brali jeńców. Był to nie tylko odwet za zbrodnie niemieckie na ziemiach ZSRR popełnione w latach 1941-1944, ale wynikało to też z bardzo prozaicznego faktu. Jeńców nie miał kto eskortować, wreszcie nie miał kto ich pilnować. Można to było robić w ostatnich dniach walk, ale nie w okresie, gdy na sąsiednich ulicach, a nawet domach czy piętrach budynków, był swoisty „przekładaniec” - sił niemieckich i radzieckich. Znamienna jest instrukcja W. Czujkowa wydana żołnierzom szturmującym Berlin:

\footnotetext{
${ }^{43}$ Ibidem, s. 24-26.

${ }^{44}$ Ibidem, s. 28.
} 
Rzuć granat i ruszaj szybko, zdecydowanie. Wykazuj inicjatywę i dużą odporność - w każdej chwili może się wydarzyć coś nieoczekiwanego. Musisz zawsze umieć się odnaleźć w labiryncie pokoi i korytarzy, pełnych niebezpieczeństw. Rzuć granat w każdy kąt. Posuwaj się do przodu. Strzelaj z pistoletu maszynowego w każdy ocalały kawałek sufitu. Przed wejściem do kolejnego pokoju znowu rzuć granat. Potem strzelaj z pistoletu maszynowego. Nigdy nie trać ani chwili ${ }^{45}$.

Trzeba przyznać, iż była to szczegółowa instrukcja postępowania podczas walk miejskich - choć okrutna. Nie ma w niej miejsca na moment zastanowienia, czy w którymś z pomieszczeń nie ma osób cywilnych. Zresztą członkowie Volkssturmu nie nosili munduru, a opaska na ubraniu nie zawsze była widoczna.

Rosyjską metodą - według Sławomira Gowina ${ }^{46}$ - na „zmiękczenie” niemieckiej obrony było ostrzeliwanie miasta z dział dużego kalibru - m.in. 600 mm, oczywiście przed wejściem do miasta własnych oddziałów. Rosjanie nie mieli jednak w 1945 r. takiej broni. Niemcy podczas powstania warszawskiego ostrzeliwali stolicę Polski z samobieżnego moździerza „60-cm Karl Gerät 040 ”. Z tego typu moździerza o nazwie „Karl” wystrzelili pocisk i poważnie uszkodzili słynny przedwojenny wieżowiec „Prudential”. W sumie podczas powstania oddano 20 strzałów z tej broni. Jeden z pocisków odnaleziono w 2012 roku podczas budowy metra w Warszawie ${ }^{47}$. Zdaniem Tymoteusza Pawłowskiego skonstruowano takie nieskuteczne monstra dla podkreślenia własnego ego dyktatorów pokroju Adolfa Hitlera czy J. Stalina, a ich skuteczność bojowa była mocno wątpliwa ${ }^{48}$.

Należy jednak sądzić, iż Rosjanie wyciągnęli także wnioski z przebiegu walk powstania warszawskiego, kiedy teoretycznie i de facto słabszy przeciwnik bronił się ponad dwa miesiące. Nawiasem mówiąc, wbrew potocznej opinii, pod względem sztuki wojskowej powstanie było bardzo dobrze przygotowane ${ }^{49}$. Radzieccy teoretycy wojskowości w swych opracowaniach nie mogli powoływać się na korzystanie z polskich doświadczeń, jako że w czasach stalinowskich powstanie warszawskie, zarówno w ZSRR, jak i potem w Polskiej Rzeczpospolitej

\footnotetext{
45 Ibidem, s. 30.

46 Ibidem.

${ }^{47}$ Jest ozdobą kolekcji Muzeum Czołgów w Kubince pod Moskwą.

48 https://opinie.wp.pl/karl-olbrzymi-niemiecki-moździerz (dostęp: 4 XI 2020).

49 Vide: T. SAWICKI, Operacyjne zagadnienia powstania warszawskiego, „Wojskowy Przegląd Historyczny" 1996, R. 41, nr 2, s. 121.
} 
Ludowej, przedstawiane było jako wystąpienie wymierzone przeciwko ZSRR, a wywołane przez reakcyjne kręgi polskiego podziemia i rządu emigracyjnego ${ }^{50}$. Wróćmy do głównego nurtu niniejszych rozważań. W czasie walk w samym Berlinie ogień artylerii mógł zagrozić własnym oddziałom. Wspomina o tym gen. Grigorij Nadysiew, w czasie walk o Berlin szef sztabu artylerii 1. Frontu Białoruskiego: „wytworzyła się taka sytuacja, w której ogień artylerii strzelającej z zakrytych stanowisk stał się nawet niebezpieczny dla własnych jednostek (...) nadeszła pora do stopniowego wstrzymywania ognia artylerii strzelającej ze stanowisk zakrytych" ${ }^{51}$. Wycofane z miasta działa wykorzystywano na osłonę tyłów własnych wojsk przed grupami dywersyjnymi nieprzyjaciela.

Specyfiką walk w tak dużym mieście, jakim był Berlin - w dodatku mieście zrujnowanym, co sprzyjało jego obrońcom - było to, że właściwie walczyły ze sobą małe grupy. Idealną bronią przeciwko pojazdom pancernym w takich warunkach były niemieckie pancerfausty. Spośród 204 czołgów straconych przez 2. Armię Pancerną, połowę z nich zniszczyły te bezodrzutowe granatniki przeciwpancerne jednorazowego użytku ${ }^{52}$.

Oceniając walki o Berlin, radzieccy dowódcy uważali, iż broniącym się łatwiej jest ustawić stanowiska karabinów maszynowych i moździerzy, a atakujący mogą je zniszczyć jedynie ogniem bezpośrednim. W wydanej w 1963 r. $\mathrm{w}$ ZSRR Istoriji Wojenngo Iskusstwa, opisując walki w Berlinie w kwietniu i maju 1945 r., stwierdzono:

Specyficzne warunki walki w dużym mieście spowodowały w szeregu przypadków szczególne sposoby użycia różnych rodzajów wojsk. W dywizjach i korpusach tworzono grupy artylerii burzenia, a w armiach ogólnowojskowych grupy artylerii dalekiego działania. Znaczna część artylerii działała w składzie oddziałów i grup szturmowych, jako artyleria do ognia wprost ${ }^{53}$.

50 J. RABIŃSKI, Powstanie warszawskie w świetle historiografii polskiej z lat 1953-1956, „Roczniki Humanistyczne" 2002, t. 50, z. 2, s. 211-230; N. Ivanov, Powstanie Warszawskie widziane z Moskwy, Kraków 2010.

${ }^{51}$ G. NAdysiew, Moja stużba w sztabach, Warszawa 1979, s. 284.

52 J. Wolfram, A. Zasieczny, Broń piechoty Wehrmachtu 1939-1945, Warszawa 2009, s. 125-128; I. HogG, Artyleria XX wieku, Warszawa 2010, s. 158. Była to broń tania, prosta w obsłudze, a żołnierze mówili na nią pieszczotliwie „Gretchen”. Produkowano ją w kilku wersjach: od Pz30 do Pz150 (cyfra oznacza optymalny zasięg).

53 Historia sztuki wojennej, red. P.A. Rotmistrow, Warszawa 1965, s. 550-551. 
W Berlinie czołgi mogły działać tylko w ścisłej współpracy z piechotą i pod jej osłoną. Samodzielne działania broni pancernej oznaczały jej zniszczenie przez Niemców.

W przypadku samodzielnych jednostek i taktycznych związków pancernych - korpusów i brygad pancernych, nacierały one nie całym frontem, ale wzdłuż głównych magistrali miasta. Batalion czołgów przemieszczał się zwykle wzdłuż jednej lub dwóch ulic, a brygada zmechanizowana nacierała wzdłuż czterech, pięciu ulic.

Pojawił się problem z użyciem lotnictwa nad Berlinem. Miasto cały czas płonęło i było spowite dymem. Akcję bombardowania stanowisk niemieckich mogły przeprowadzać tylko pojedyncze samoloty. Z tego powodu gros sił lotnictwa bombowego i szturmowego zostało wykorzystane do niszczenia frankfurcko-gubeńskiego zgrupowania przeciwnika, a lotnictwo myśliwskie wykonywało powietrzną blokadę Berlina ${ }^{54}$.

Podsumowując swe rozważania, autorzy Istoriji Wojenngo Iskusstwa napisali: „Tak więc główny ciężar walki o Berlin spadł na barki wojsk lądowych. Walki w mieście miały charakter niezwykle zacięty i uporczywy, i nie ustawały ani w dzień, ani w nocy"55.

Szturmujące od 26 kwietnia 1945 r. Berlin siły Armii Czerwonej liczyły: 464 tys. żołnierzy, 12,3 tys. dział, 2,1 tys. wyrzutni rakietowych, 1,5 tys. czołgów i dział pancernych. W stolicy III Rzeszy zginęło 200 tys. żołnierzy i cywili oraz 300 tys. czerwonoarmistów. Strona radziecka rozbiła podczas całej operacji berlińskiej (16 kwietnia - 2 maja 1945) 70 dywizji piechoty oraz 23 dywizje pancerne i zmechanizowane. Zdobyto 11 tys. armat i moździerzy, ponad 1,5 tys. czołgów i dział pancernych, ok. 4,5 tys. samolotów. Do niewoli wzięto 480 tys. żołnierzy niemieckich ${ }^{56}$.

W wypracowanej w latach wojny doktrynie wojennej, gdy nie zachodziła taka potrzeba, unikano zdobywania miast, stosując manewr oskrzydlający, który potem pozwalał zamknąć miasto w kleszczach oblężenia. Nie wynikało to $\mathrm{z}$ chęci uniknięcia niepotrzebnych strat własnych czy ludności cywilnej, ale

\footnotetext{
${ }^{54}$ Ibidem, s. 551-552.

55 Ibidem, s. 552; J. PAŁKA, Berliński finat, [w:] II wojna..., t. 10, s. 126-127. Przegrupowania pododdziałów najczęściej przeprowadzano nocą.

${ }^{56}$ Oczywiście nie w samym Berlinie, a w całej operacji berlińskiej. Vide: S. Gowin, op. cit., s. 4-5; J. PAŁKA, op. cit., s. 128.
} 
z faktu, iż naczelnym zadaniem Armii Czerwonej, postawionym przez J. Stalina, było zdobycie Berlina i zajęcie maksymalnie dużego terytorium Niemiec. Oczywiście we wspomnieniach wyższych dowódców radzieckich nie znajdziemy takiego stwierdzenia. Jak napisali np. autorzy monografii radzieckiej 4. Armii Gwardii:

Radzieccy żołnierze, wkraczając na terytorium Austrii, swoim humanizmem obalili wszystkie oszczerstwa obłudnej goebbelsowskiej propagandy o Radzieckich Siłach Zbrojnych. Naród austriacki zobaczył, że Armia Radziecka wkroczyła nie po to, by zemścić się za to, że państwo austriackie pomagało faszystowskim Niemcom w wojnie przeciwko ZSRR. Weszła nie jako zdobywca, ale jako wyzwolicielka ludu Austrii od tyranii faszyzmu ${ }^{57}$.

Parę stron dalej możemy przeczytać credo żołnierza Czwartej Gwardyjskiej: „Ja obroniłem Stalingrad, ja wygnałem faszystów z Budapesztu, ja wyzwoliłem Wiedeń!"58.

Marzeniem wyższych dowódców Armii Czerwonej w latach wojny było zdobycie miasta z marszu. Nie zawsze się to udawało. Takie szczęście miał mjr Siemion Chochriakow. W styczniu 1945 r. dowodził 209. batalionem czołgów 54. Gwardyjskiej Brygady Czołgów 7. Korpusu Pancernego Gwardii. Po zaciętych walkach swego macierzystego korpusu nad Pilicą jego pododdział oderwał się od własnej brygady i 16 stycznia wjechał do Częstochowy, ku zaskoczeniu sił niemieckich szykujących się dopiero do obrony miasta. W nocy z 16 na 17 stycznia dotarły do 209. batalionu radzieckie czołgi nacierające od północy, a wkrótce i radziecki oddział wydzielony wysłany na wsparcie pododdziału S. Chochriakowa przez dowódcę 1. Frontu Ukraińskiego I. Koniewa. Wczesnym rankiem 17 stycznia 1945 r. miasto zostało ostatecznie zdobyte. Widać więc, że na wojnie często karty rozdaje ślepy los ${ }^{59}$.

57 Т.Ф. ВОРОНЦОВ, Н.І. БИРЮКОВ, А.Ф. СМЕКААОВ, От волжских степей до австрийских Альп. Боевой путь 4-й гвардейской армии, Москва 1971, s. 207-208.

$58 \mathrm{Ibidem}$, s. 221. W tym samym tonie napisał swe wspomnienia I. KonIEw (Notatki dowódcy frontu 1943-1945, Warszawa 1986, s. 387-617).

59 Dowódca 209. batalionu czołgów był dwukrotnym Bohaterem Związku Radzieckiego (drugi tytuł otrzymał za zdobycie Częstochowy). Zginął 17 IV 1945 r. pod Cottbus. Vide: B. DolatA, Wyzwolenie Polski 1944-1945, Warszawa 1974, s. 200-203; http://www.hrono.ru/biograf/bio_h/ hohryakov.html (dostęp: $21 \mathrm{~V}$ 2021); https://www.muzeumczestochowa.pl/inne/wolna-czestochowa (dostęp: 17 I 2021). 
Takiego szczęścia nie miał inny pancerniak radziecki - płk Mikołaj Morgunow, dowódca 45. Brygady Pancernej Gwardii z 1. Armii Pancernej, który 4 marca 1945 r. próbował z marszu zająć Kołobrzeg. Miasto to w niemieckim systemie obrony w 1945 roku spełniało bardzo istotną rolę jako ważny punkt ewakuacyjny i baza morska. Mogły tu lądować oddziały desantowe przeznaczone do uderzeń na skrzydło wojsk radzieckich działających na kierunku berlińskim. Niemcy, wykorzystując podmiejskie tereny bagniste, rzekę Parsętę i Kanał Drzewny, w 1944 r. rozpoczęli budowę umocnień w mieście. Obrońcy dysponowali ciężkimi działami artylerii nadbrzeżnej, artylerią okrętów Kriegsmarine, pociągiem pancernym, czołgami i działami pancernymi.

Wykorzystując te atuty, Niemcy już 5 marca odrzucili brygadę M. Morgunowa z południowo-zachodniej części miasta. Jego bezpośredni przełożony, dowódca 1. Armii Pancernej gen. Michał Katukow, krytycznie ocenił działania swego podwładnego: „Morgunow już czwarty rok dowodził brygadą. Był to doświadczony i odważny dowódca. Tym razem jednak popełnił błąd, a ściślej przejawił niezdecydowanie. Po oderwaniu się od sił głównych na $20-25 \mathrm{~km}$ postanowił zaczekać na nie i zwolnił tempo natarcia"60. Tym samym zmarnował element zaskoczenia, który jest bardzo ważny przy atakowaniu miast z marszu. Ciekawe, że podobnie jak M. Katukow, ocenili działania dowódcy 45. Brygady również Niemcy, którzy dopiero 4 marca kończyli całościowe przygotowania do obrony.

Kołobrzeg ostatecznie zajęły jednostki 1 . Armii WP, rozpoczynając oblężenie miasta w dniu 7 marca. Walki o miasto zakończono nad ranem 18 marca 1945 r. zdobyciem stacji kolejowej i portu. Zdaniem Hieronima Kroczyńskiego zdobycie było zasadne ze względów strategicznych, gdyż Niemcy stracili port, ale opłacono ten sukces zbyt dużą daniną krwi. W walkach o miasto zginęło bądź zmarło z ran 1,3 tys. polskich żołnierzy, a ponad 2 tys. zostało rannych. Straty radzieckie też liczone były w setkach ofiar. Niestety, była to ciemna strona wielu sukcesów Armii Czerwonej ${ }^{61}$.

Ciekawe są uwagi uczestnika walk o Kołobrzeg, później znanego historyka wojskowości, Tadeusza Rawskiego: „Walki w mieście trzeba się nauczyć - las jest zupełnie inny. Żołnierz schowa się za drzewo, rzuci się w krzaki, granat

\footnotetext{
${ }^{60}$ H. KRoczYŃSKI, Twierdza Kotobrzeg, Warszawa 1998, s. 80.

${ }^{61}$ Ibidem, s. 84-86; https://wikipedia.org/wiki,Bitwa_o_Ko\%C5\%82obrzeg (dostęp: 17 I 2021); https://twierdzakolobrzeg.pl/twierdza/rok-1945/193-4-6-marca-ida-rosjanie (dostęp: 15 I 2021).
} 
nie przebije. Co innego w murach. Do bon tonu należało na przykład chodzenie w rogatywce, bo rogatywka pokazywała wyraźnie przynależność do wojska polskiego. Walki w mieście pokazały konieczność noszenia hełmów”62. Zrozumiałym jest w tej sytuacji, iż w 1. i 2. Armii WP dowódcy pododdziałów chcieli mieć w swych szeregach byłych powstańców warszawskich, którzy nauczyli się walczyć w mieście w naprawdę ekstremalnych warunkach.

Należy stwierdzić, że praktycznie kadra dowódcza armii europejskich, podobnie jak i amerykańskiej, przed II wojną światową nie przewidywała prowadzenia walk w mieście. Czym innym jest bowiem bitwa o miasto, staczana pod miastem, od tej, do którego później się wkraczało. Tak było chociażby w latach 1914-1918. W związku z tym w okresie międzywojennym nie ćwiczono należycie zachowań żołnierzy $\mathrm{w}$ rejonie zurbanizowanym, co jest normą we współczesnych siłach zbrojnych. We współczesnym Wojsku Polskim używa się pojęcia „taktyka zielona”, czyli działania poza miastem, w przeciwieństwie do „taktyki czarnej” - walki w rejonie zurbanizowanym ${ }^{63}$.

Oceniając w latach siedemdziesiątych udział Armii Czerwonej w zmaganiach II wojny światowej, historycy radzieccy zwracali uwagę, że w latach 1941-1945 dowódcy RKKA cały czas uczyli się taktyki i dowodzenia. Zdobywali cenne doświadczenia bojowe podczas obrony Moskwy w 1941 r., walk o Stalingrad, największej bitwy pancernej na łuku kurskim w lecie 1943 r. czy podczas operacji berlińskiej ${ }^{64}$.

Iwan Koniew, dowódca 1. Frontu Ukraińskiego, który przegrał wyścig do Berlina z G. Żukowem, tak wspominał lata wojny: „Doświadczenie wojenne to wielka rzecz. (...) Kiedy wspominam wojnę i porównuję jej różne etapy, wydaje mi się, że niekiedy nie doceniamy drogi, jaką przebyliśmy w opanowaniu sztuki wojennej w latach wojny" ${ }^{\prime \prime}$.

${ }^{62}$ https://dzieje.pl/aktualnosci/bitwa-o-kolobrzeg (dostęp: 12 I 2021); https://twojahistoria. pl/2020/13/jak-niemcy-bronili-kolobrzegu (dostęp: 11 I 2021).

${ }^{63}$ K. POKONIECZNY, M. WYSZYŃSKI, Wojskowa ocena terenu z wykorzystaniem systemu informacji przestrzennej, „Kwartalnik Bellona” 2016, R. 48 (10), s. 184-184; T. WóJTOWICZ, op. cit., s. 134-142.

${ }^{64}$ История Второй мировой войнь 1939-1945, t. 10 (Завершение разгрома фашистской Германии), Москва 1979, s. 439-450.

${ }^{65}$ I. KONIEW, Notatki dowódcy frontu 1943-1945, Warszawa 1986, s. 483. Podobnie myśleli także amerykańscy dowódcy, posyłając do walki w miastach północnych Włoch żołnierzy, którzy już zdobyli doświadczenie w walkach na obszarach zurbanizowanych. Vide: K. vON TIPPELSKIRCH, op. cit., s. 304-310, 337-343, 371-382; J. Holland, Piekto Italii. Kampania wtoska 1944-1945. Od Monte Cassino do kapitulacji, Warszawa 2008. 
W niniejszym artykule, chociażby z racji na jego objętość, ukazano tylko wybrane przykłady walk Armii Czerwonej w mieście, głównie w wielkich aglomeracjach, takich jak Berlin. Walki w mniejszych ośrodkach miejskich stwarzają podobne problemy, inna jest tylko ich skala. W praktyce przed wybuchem II wojny światowej rozważano raczej prowadzenie działań dywersyjnych w miastach niż walki na ulicach ośrodków miejskich. Planowano raczej oblężenie miast i zmuszenie ich, by się do poddały. Rozwój techniki wojennej, ewolucja charakteru działań wojennych w kierunku wojny totalnej, wymogły na wyższych dowódcach RKKA wypracowanie form taktyki walki w gęstej zabudowie miejskiej. Zdaniem autora - tacy dowódcy jak G. Żukow, W. Czujkow czy K. Rokossowski, szybko poznali i opanowali sztukę walki w mieście, zarówno w przypadku zmuszenia nieprzyjaciela, by niejako „utknął” z wojskami w mieście jako swego rodzaju pułapce (przykład Stalingradu), jak i w przypadku zajęcia wielkiego miasta (przykład Berlina).

\section{BIBLIOGRAFIA}

\section{Źródła archiwalne}

Archiwum Akt Nowych w Warszawie

Ambasada w Moskwie, sygn. 94.

Centralne Archiwum Wojskowe - Wojskowe Biuro Historyczne w Warszawie Oddział II SG, sygn. I.303.4.3169.

\section{Źródła drukowane}

Armia Czerwona w przededniu najcięższej próby. Materiaty z posiedzenia Rady Wojennej Robotniczo-Chtopskiej Armii Czerwonej w dniach 23-31 grudnia 1940 r., oprac. J. Budziński, C. Grzelak, Z. Matuszak, Warszawa 2006.

РККА и Гражданскал война в Испании. Сборники информачионньх материалов Разведььвательного управления, Москва 2020 (RKKA i Grażdanskaja wojna w Ispanii. Sborniki infomacyonnych matieriatow Razwiedywatielnogo uprawlenija, Moskwa 2020). 


\section{Wspomnienia}

Bagramian I., Tak wykuwaliśmy zwycięstwo, Warszawa 1980.

Czujkow W., Poczatek drogi, Warszawa 1962.

Guderian H., Wspomnienia żotnierza, Warszawa 1958.

Koniew I., Notatki dowódcy frontu 1943-1945, Warszawa 1986.

Manstein E., Stracone zwyciestwa. Wspomnienia 1939-1944, Warszawa 2001.

Montgomery B.L., Wspomnienia, Warszawa 1996.

Nadysiew G., Moja stużba w sztabach, Warszawa 1979.

Rokossowski K., Żotnierski obowiązek, Warszawa 1973.

Żukow G., Wspomnienia i refleksje, Warszawa 1973.

Чуйков В., 180 дней в огне сражений. Из записок командарма 62-й, Москва 1962 (Czuјkow W., 180 dniej w ognie srażenij. İzapisok komandarma 62-j, Moskwa 1962).

\section{Opracowania}

Baczkowski M., Kontynent europejski w latach 1789-1849, [w:] Wielka historia świata, t. 9: Świat w latach 1800-1850, red. A. Chwalba, Kraków 2006, s. 255-462.

Bazylow L., Historia Rosji, Warszawa 1985.

Białkowski W., Rokossowski - na ile Polak?, Warszawa 1994.

Britannica. Edycja polska, t. 1, Poznań 1997.

Cawthorne N., Dowódcy i generatowie. Prawdziwe historie, Warszawa 2014.

Chojnacki S., Sowiecka sztuka operacyjna w latach 1940-1941, „Studia z Dziejów Rosji i Europy Środkowo-Wschodniej” 2014, t. 49, nr 2, s. 165-184.

Chojnowski A., Izrael, Warszawa 2003.

Czernielewski K.A., Kampania 1939 roku. Przebieg, kulisy, mity..., Łódź 2019.

Czernielewski K.A., Operacja tódzka 1914 roku. W stulecie walk o nasze miasto, „Kronika Miasta Łodzi” 2014, nr 3(76), s. 84-92.

Czernielewski K.A., Polski wywiad wojskowy w latach wojny z Rosją bolszewicka. As stużb specjalnych II Rzeczypospolitej - Jan Kowalewski, Łódź 2020.

Deszczyński M.P., Warszawa niepokonana, [w:] II wojna światowa, red. K. Kurek, t. 2 (Obrona Polski), Warszawa 2009, s. 75-85.

Dolata B., Wyzwolenie Polski 1944-1945, Warszawa 1974.

Głowacki L., Obrona Warszawy i Modlina na tle kampanii wrześniowej 1939, Warszawa 1985. 
Gołębiewski G., Zanim zostat „Grotem”. Stużba Stefana Roweckiego w wojsku II Rzeczypospolitej do 1939 r., Warszawa 1995.

Gowin S., Berlin 1945, Warszawa 2005.

Grzelak C., Armia Czerwona po wojniepolsko-rosyjskiej 1919-1921, „Studia z Dziejów Wojskowości” 2014, t. 3, s. 255-265.

Grzelak C., Kresy w czerwieni, Warszawa 1998.

Grzelak C., Wilno-Grodno-Kodziowce 1939, Warszawa 2002.

Historia sztuki wojennej, red. P.A. Rotmistrow, Warszawa 1965.

Hogg I., Artyleria XX wieku, Warszawa 2010.

Holland J., Piekto Italii. Kampania wtoska 1944-1945. Od Monte Cassino do kapitulacji, Warszawa 2008.

Ivanov N., Powstanie Warszawskie widziane z Moskwy, Kraków 2010.

Kaczmarek K., Stalingrad 1942-1943, Warszawa 1985.

Klimecki M., Krym 1854-1855, Warszawa 2006.

Kołomyjec N., Wojna zimowa 1939-1940, Warszawa 2002.

Kondracki T., Stalingradzkie piekto na ziemi, [w:] II wojna światowa, red. K. Kurek, t. 10 (Front Wschodni), Warszawa 2009, s. 53-68.

Konecki T., Wojna radziecko-fińska 1939-1940, Warszawa 1998.

Krawczuk A., Gajusz Juliusz Cezar, Warszawa 1990.

Kroczyński H., Twierdza Kotobrzeg, Warszawa 1998.

Majzner R., Attachaty wojskowe Drugiej Rzeczypospolitej 1919-1945. Strukturalno-organizacyjne aspekty funkcjonowania, Częstochowa 2011.

Mossor S., Sztuka wojenna w warunkach nowoczesnej wojny, Warszawa 1938.

Newark T., 50 bitew, które zmienity bieg historii nowożytnej, Poznań 2002.

Odziemkowski J., Warszawa w wojnie obronnej 1939 roku, Warszawa 1989.

Ostrowski J.A., Rozwój i upadek Imperium Romanum, [w:] Wielka historia świata, t. 3: Świat okresu cywilizacji klasycznych, red. A. Krawczuk, Kraków 2005, s. 191-446.

Pajewski J., Pierwsza wojna światowa, Warszawa 1991.

Pałka J., Berliński finat, [w:] II wojna światowa, red. K. Kurek, t. 10: Front Wschodni, s. $122-131$.

Pepłoński A., Wywiad a dyplomacja II Rzeczypospolitej, Toruń 2004.

Perzyk B., Twierdza Osowiec 1882-1915, Warszawa 2004.

Pokonieczny K., Wyszyński M., Wojskowa ocena terenu z wykorzystaniem systemu informacji przestrzennej, „Kwartalnik Bellona” 2016, R. 48 (10), s. 175-188.

Rabiński J., Powstanie warszawskie w świetle historiografii polskiej z lat 1953-1956, „Roczniki Humanistyczne" 2002, t. 50, z. 2, s. 211-230.

Rowecki S., Walki uliczne, Warszawa 1928. 
Różański J., Twierdza Przemyśl, Rzeszów 1983.

Sawicki T., Operacyjne zagadnienia powstania warszawskiego, „Wojskowy Przegląd Historyczny” 1996, R. 41, nr 2, s. 98-122.

Sikorski W., Przyszta wojna - jej możliwości i charakter oraz związane z nimi zagadnienia obrony kraju, Warszawa 1934.

Smoliński A., Armia Czerwona oraz sowiecki potencjat militarny z lat dwudziestych i trzydziestych XX w. w dokumentach Oddziatu II Sztabu Gtównego Wojska Polskiego. Przyczynek do dziejów i efektywności wywiadu wojskowego II Rzeczypospolitej, [w:] Studia nad wywiadem ikontrwywiadem Polski w XX wieku, t. 3, red. W. Skóra, P. Skubisz, Szczecin 2016, s. 63-144.

Southern P., Juliusz Cezar, Warszawa 2002.

Suworow W., Cofam wypowiedziane stowa, Poznań 2014.

Suworow W., Klęska, Poznań 2010.

Wap A., Twierdza Osowiec - zarys dziejów, Białystok 1994.

Weisberger B.A, Wojna secesyjna 1861-1865, [w:] Historia Stanów Zjednoczonych Ameryki, red. W. Nugent, H. Parafianowicz, t. 3 (1848-1917), Warszawa 1985, s. 37-66.

Wolfram J., Zasieczny A., Broń piechoty Wehrmachtu 1939-1945, Warszawa 2009.

Wołos M., Udziat obywateli Zwiazku Sowieckiego w wojnie domowej w Hiszpanii w latach 1936-1939, „Acta Universitatis Lodziensis. Folia Historica” 2016, t. 97, s. 31-63.

Wójtowicz T., Rola miast $w$ strategii militarnej. Prowadzenie walk $w$ terenie zurbanizowanym na przyktadzie II wojny w Zatoce Perskiej, „Zeszyty Naukowe Wyższej Szkoły Europejskiej im. ks. Józefa Tischnera w Krakowie” 2008, nr 4, s. 131-142.

Воронцов Т.Ф., Бирюков Н.I., Смекалов А.Ф., От волжских степей до австрийских Альп. Боевой путь 4-й гвардейской армии, Москва 1971 (Woroncow T.F., Birjukow H.I., Smiekałow A.F., Od wotżskich stiepiej do awstrijskich Al'p. Bojewoj put' 4-jgwardjejskoj armiji, Moskwa 1971).

Военньцй Энииклопедический Словарь, Москва 1983 (Wojennyj Enciktopiedicziejskij Stowar, Moskwa 1983).

История Второй мировой войнь 1939-1945, Т. 10 (Завершение разгрома фашистской Германии), Москва 1979 (Istorija wtoroj mirowoj wojny 1939-1945, t. 10 (Zawierszenije razgroma faszistkoj Giemaniji), Moskwa 1979).

Корабцьов Ю., Зашита Республики. Как создавалась Рабоче-Крестьянскал Красная Армия. Переписка на исторические темь: диалог ведёт читатель, Москва 1989 (Korablow J., Zaszczita Riespubliki. Kak sozdawatas' Rabocze-Kriestjanskaja Krasnaja Armmija. Pieriepiska na istoriczeskije tiemy: diatog wiediot czitatiel, Moskwa 1989).

Типпельскирх К., История Второй мировой войньь, Москва 1956 (Tippelskirch K., Istorija wtoroj mirowoj wojny, Moskwa 1956). 


\section{Netografia}

https://artsandculture.google.com/exhit/hiszpanska-wojna-domowa (dostęp: 5 I 2021).

https://dzieje.pl/aktualnosci/bitwa-o-kolobrzeg (dostęp: 12 I 2021).

https://opinie.wp.pl/karl-olbrzymi-niemiecki-moździerz (dostęp: 4 XI 2020).

https://pl.wikiquote.org/wiki/Wasilij_Czujkow (dostęp: 17 I 2021).

https://twierdzakolobrzeg.pl/twierdza/rok-1945/193-4-6-marca-ida-rosjanie(dostęp: 15I2021).

https://twojahistoria.pl/2020/13/jak-niemcy-bronili-kolobrzegu (dostęp: 11 I 2021).

https://wikipedia.org/wiki,Bitwa_o_Ko\%C5\%82obrzeg (dostęp: 17 I 2021).

https://wikipedia.org/wiki/Twierdza_Li\%C3\%A8ga (dostęp: 7 XII 2020).

http://www.hrono.ru/biograf/bio_h/hohryakov.html (dostęp: 21 V 2021).

https://www.muzeumczestochowa.pl/inne/wolna-czestochowa (dostęp: 17 I 2021).

www.sww.w.szu.pl/index.php.?id=bitwa_stalingrad (dostęp: 30 XII 2020).

\section{Konrad Aleksander Czernielewski}

\section{FIGHTING IN THE CITY IN THE MILITARY THOUGHT OF THE WORKERS' AND PEASANTS' RED ARMY (1918-1946)}

Summary. The author of the paper presented the views of theoreticians and commanders of the Workers' and Peasants' Red Army (WPRA) for city fighting and conquering, since the uprising Red Army in February 1918 until the end of World War II. He discussed how the senior officers of the Red Army viewed the issue of the specificity of combat in an urbanized area - which is nowadays referred to as the black tactic. He also presented the problem - always important for commanders of both infantry, armored weapons, artillery and aviation - whether to capture cities from the front or rather encircle - forcing the enemy to withdraw his forces. The author discussed it mainly on the basis of the battles in Stalingrad and Berlin. The battles in the latter city are called the Berlin Strategic Offensive Operation in the Soviet historiography. He also described the circumstances of the attack on Bobruisk during Operation Bagration. In the latter case, a dispute arose between Joseph Stalin, who was a supporter of a massive attack on this city, and Konstanty Rokossowski, who insisted on concentrically attacking along both banks of the Berezina. Interestingly, in this dispute, the Generalissimo finally agreed with K. Rokossowski. The author also presented the unsuccessful attempt to capture Kołobrzeg from the $45^{\text {th }}$ Armored Brigade of the Guard of Col. Mikołaj Morgunow from the composition of the $1^{\text {st }}$ Panzer Army of General Col. Mikhail Katukov and the successful campaign to capture Częstochowa from the march. The paper presents the views of the most important Soviet commanders of the Second World War: Grigory Zhukov, Konstanty Rokossowski, Ivan Koniev, Ivan Bagramian, Vasily Chukov, Grigory Nadysiew, and the German ones: Erich von Mannstein and Heinz Guderian.

Keywords: Red Army, Soviet Union, city fights, tactics, strategy, maneuver, encirclement 
